\title{
Evaluation of Plant Extracts against Stemphylium Blight of Lentil
}

\author{
S. Subedi ${ }^{1}$, S.M. Shrestha ${ }^{2}$, G.B. KC ${ }^{2}$, R.B. Thapa ${ }^{2}$, S.K. Ghimire ${ }^{3}$, \\ D.B. Gharti ${ }^{1}$ and $\mathrm{S}$. Neupane ${ }^{4}$ \\ ${ }^{1}$ Nepal Agricultural Research Council, Grain Legumes Research Program, Banke, Nepal \\ ${ }^{2}$ Institute of Agriculture and Animal Science, Tribhuvan University, Kathmandu, Nepal \\ ${ }^{3}$ Agriculture and Forestry University (AFU), Chitwan, Nepal \\ ${ }^{4}$ Nepal Agricultural Research Council, National Maize Research Program, \\ Chitwan, Nepal \\ e-mail: subedi.subash1@gmail.com
}

\begin{abstract}
Experiments were carried out to evaluate five different plant extracts against lentil stemphylium blight (Stemphylium botryosum Walr.) at the Grain Legume Research Program, Rampur, Chitwan, Nepal during two winter seasons (2011/ 12 and 2012/13) using CRD in laboratory and RCBD in field conditions. Water extract of Acorus calamus at higher dose $(8 \% \mathrm{~W} / \mathrm{V})$ was able to check the growth of the pathogen completely in-vitro. The mycelial growth inhibition (\%) of Xanthoxylum armatum and Lantana camera at 8\% concentration in PDA were 31.17 and 24.56 respectively. In the field experiment during 2011/12, extracts were sparingly effective for a short period. However the disease control (PDC) was higher in X. armatum treated plot (31.60\%) followed by A. calamaus (28.69\%) and L. camera $(27.61 \%)$ when compared to unsprayed plot. The following year (2012/13) field experimental results also verified the effect of plant extracts against the disease. The lower Disease (\%) Index (PDI) was obtained from the plots treated with A. calamus (35.33\%) and X. armatum (35.55\%). Higher crop yield was recorded from the plot treated with $A$. calamus $(987.39 \mathrm{~kg} / \mathrm{ha})$ followed by $X$. armatum $(972.78 \mathrm{~kg} / \mathrm{ha})$. Two years' experimental results revealed that $A$. calamus and $X$. armatum were effective botanicals to manage lentil Stemphylium blight.
\end{abstract}

Key words: lentil, plant extracts, Stemphylium botryosum

\section{Introduction}

Lentil is affected by wide range of pathogens along with fungal diseases being the most important. Stemphylium blight (Stemphylium botryosum Walr.) is becoming a serious threat to lentil cultivation. In Bangladesh and India, estimated yield losses were about $62 \%$ and total crop failure had been reported in some cases (Bakr 1991). This disease defoliates the crop in the early pod setting stage (Ersksine \& Sarker 1997). In Nepal, it was observed increasingly in lentil fields in Banke, Bardia, Rupandehi, Chitwan, Nepalgunj, Makwanpur, Bara, Parsa and Rautahat districts (Joshi 2006). It was first reported in 1993 in Nepal, and the dangerous consequences to man and environment necessitated the search for and the development of ecologically sustainable fungi control methods This is a better strategy to make disease control mechanism effective against the target species, with a minimal adversity on non-target species. Due to the problems like chemical residues, biodegradation, phytotoxicity and pollution associated with chemical control strategies, alternative fungi control methods are being attempted. The main aim of this study is to provide useful information on cheaper, affordable and environmentally friendly pesticide in the control of Stemphylium blight disease of lentil.

\section{Methodology}

Both laboratory and field experiments were conducted to study on the efficacy of plant extracts against 
stemphylium blight of lentil at the Grain Legumes Research Program (GLRP), Rampur, Chitwan, Nepal during period of 2011-2013. Lab works were carried out to calculate the growth of the pathogen at different concentrations of plant extracts, incubated for 25 days at $30^{\circ} \mathrm{C}$, by poisoned food technique at the laboratory of GLRP. Five different botanicals Nepal pepper/Prickly ash (Xanthoxylum armatum), Neem (Azadirachta indica), sweet flag (Acorus calamus), mug-wort (Artemisia indica) and lantana (Lantana camara) were selected for the study. Dried fruits of Nepal pepper, stolos of sweet flag and fresh leaves of the other three species were used. These materials were dried in the shed for two days. While preparing the extracts, the unwanted debris were removed, surface sterilized for 2 minute in $70 \%$ ethanol, and washed in three changes of sterile distilled water. The paste was obtained by grinding $2 \mathrm{~g}, 4 \mathrm{~g}, 6 \mathrm{~g}$ and $8 \mathrm{~g}$ each of Nepal pepper, sweet flag, mug-wort, neem and lantana plants separately in $100 \mathrm{ml}$ of sterile distilled water using an electrical grinder. The paste was squeezed and filtered through 4 folds of sterile cotton wool into a $150 \mathrm{ml}$ conical flask to give concentrations of $2 \%, 4 \%$, $6 \%$ and $8 \%$ (Wokocha \& Okereke 2005). The volume of the filtrate collected was $100 \mathrm{ml}$ and each of the extract concentration was kept aseptically in $150 \mathrm{ml}$ conical flasks. The content in the flasks was exposed to UV light for further sterilization. Different concentrations of water extracts of plants were individually incorporated into different conical flasks containing $100 \mathrm{ml}$ of sterile molten potato dextrose agar medium prepared from the dehydrated PDA (HIMEDIA, REF MO96-500G) as per the instructions of the manufacturer in the laboratory condition. The extracts were added to the PDA when it was cooled to about $50^{\circ} \mathrm{C}$ with the help of micro-pipette. The flasks were gently agitated for 2 min to allow for a proper mixing of extract with the nutritive medium then $20 \mathrm{ml}$ medium was poured in the petri-plates $(9 \mathrm{~cm}$ diam). Strepto-penicillin (Bistrepen-V) (250 mg per liter) was added to the medium at the time of pouring to prevent bacterial contamination. There were a total of six different treatments consisting of Nepal pepper, sweet flag, mugwort, neem, lantana and control. The concentration was maintained to $2 \%, 4 \%, 6 \%$ and $8 \%$. There were 5 experimental setting consisting of Nepal pepper, sweet flag, mug-wort, neem, lantana extract. Each experiment included 5 treatments; plant extract at 2\%, 4\%,6\% and $8 \%$ concentration levels including control (without any extract). Four millimetre diameter of S. botryosum of one week old culture was cut by cork borer and picked up with the help of inoculating needle and placed onto the center of the PDA plate amended with botanicals as upside down for better contact of pathogen to the media. The plates were incubated at $30^{\circ} \mathrm{C}$ up to 25 days.

The colony diameter $(\mathrm{cm})$ of the pathogen was determined by measuring the average radial growth on different incubation dates. Average radial growth was recorded by using a measuring scale from the lower view of the petri-plates. Mycelial growth inhibition (percent) was calculated by following formula.

Mycelial growth inhibition $(\%)=[(\mathrm{dc}-\mathrm{dt}) / \mathrm{dc}] \times 100$ Where $\mathrm{dc}=$ average diameter of fungal colony in the control

$\mathrm{dt}=$ average diameter of fungal colony in the treatment group

\section{In-vivo test (Experiment under field condition)}

The experiment was conducted under natural epiphytotic condition following a randomized complete block design. The unit plot size was $4 \mathrm{~m} \times 1.5 \mathrm{~m}$ with $25 \mathrm{~cm}$ row to row spacing. A susceptible lentil variety Shital was sown on November $23^{\text {rd }}$ of 2011 and 2012. There were altogether six treatments comprising five different botanicals i.e. Nepal pepper, neem, sweet flag, mug-wort and lantana with concentration $(8 \% \mathrm{~W} / \mathrm{V})$ and one control (without extract). All treatments were replicated four times. First spray was done just after the appearance of disease symptom during the initiation of flowering period of the crop (60-70 days after sowing for all experiments). In total three sprays were done at an interval of 15 days. Disease severity data were recorded before every spray using 19 scoring scale from 25 randomly tagged plants/plot (Morrall \& Mckenzie 1974).

Similarly percent disease index (PDI) was computed on the basis of recorded data according to the formula of Wheeler (1969) and calculation was based on the final data recorded at 15 days after the last spray. Percent disease control (PDC) was calculated on the basis of the formula developed by Shivankar and Wangikar (1993).

Early plant stand (EPS) and final plant stand (FPS) were recorded according to the scale developed by International Center for Agricultural Research in the Dry Areas, Aleppo, Syria(ICARDA 2012). Data were recorded on yield and yield attributes after necessary sun drying. Yield increase over the control was calculated. All data 
were analyzed statistically using MSTAT-C. Analysis of variance was done. Treatment means were compared using Duncan's Multiple Range Test (DMRT) at one and five percent levels of significance.

\section{Results and Discussion}

\section{In-vitro test}

Effect of botanicals on mycelial growth inhibition (percent) of S. botryosum

All botanicals except mug-wort (A. indica) and neem (A. indica) even at a lowest dose also inhibited radial mycelial growth of the pathogen significantly over the control at different concentrations. A. calamus at highest dose (6\% on PDA) was able to completely check the growth of the pathogen $(0.40 \mathrm{~cm})$. With the increase in concentration $(8 \%)$, the mean colony diameter of the pathogen in the plate amended with $X$. armatum (5.83 $\mathrm{cm})$ and $L$. camera $(6.80 \mathrm{~cm})$ was significantly lower than the diameter recorded at control plate $(8.47 \mathrm{~cm})$. The mycelial growth inhibition percent of $X$. armatum, and $L$. camera was 31.17 and 24.56 respectively (Table 1 ).

Table 1. Effect of different botanicals incorporated PDA on the growth and mycelia inhibition (\%) of S. botryosum on $20^{\text {th }}$ day of incubation period at $30^{\circ} \mathrm{C}$ temperature during 2011/12

\begin{tabular}{|c|c|c|c|c|c|c|c|c|}
\hline \multirow[t]{2}{*}{ Treatments } & \multicolumn{2}{|c|}{$\begin{array}{l}X . \text { armatum (Nepal } \\
\text { pepper) }\end{array}$} & \multicolumn{2}{|c|}{$\begin{array}{l}\text { A. Calamus (Sweet } \\
\text { flag) }\end{array}$} & \multicolumn{2}{|c|}{$\begin{array}{l}\text { L. camera } \\
\text { (Lantana) }\end{array}$} & \multirow{2}{*}{$\begin{array}{l}\text { A. indica (Mug- } \\
\text { wort) } \\
\text { MCD (cm) }\end{array}$} & \multirow{2}{*}{$\begin{array}{l}\text { A. indica } \\
\text { (Neem) } \\
\text { MCD }(\mathrm{cm})\end{array}$} \\
\hline & $\begin{array}{l}\text { MCD } \\
(\mathrm{cm})\end{array}$ & $\begin{array}{l}\text { MGI } \\
\%\end{array}$ & $\begin{array}{l}\text { MCD } \\
(\mathrm{cm})\end{array}$ & $\begin{array}{l}\text { MGI } \\
\%\end{array}$ & $\begin{array}{l}\text { MCD } \\
(\mathbf{c m})\end{array}$ & $\begin{array}{l}\text { MGI } \\
\%\end{array}$ & & \\
\hline $2 \%$ on PDA & $7.67^{\text {b† }}$ & 9.44 & $4.00^{\mathrm{b}}$ & 52.94 & $7.00^{\mathrm{bc}}$ & 17.35 & $7.57^{\mathrm{c}}$ & $8.37^{\mathrm{bc}}$ \\
\hline $4 \%$ on PDA & $7.33^{b}$ & 13.46 & $2.00^{\mathrm{c}}$ & 76.47 & $7.23^{\mathrm{bc}}$ & 14.64 & $8.50^{\mathrm{ab}}$ & $8.47^{\mathrm{ab}}$ \\
\hline $6 \%$ on PDA & $6.67^{c}$ & 21.25 & $0.40^{\mathrm{d}}$ & 95.29 & $7.33^{\mathrm{b}}$ & 13.46 & $8.07^{\mathrm{abc}}$ & $8.67^{\mathrm{ab}}$ \\
\hline $8 \%$ on PDA & $5.83^{\mathrm{d}}$ & 31.17 & $0.40^{\mathrm{d}}$ & 95.29 & $6.80^{\mathrm{c}}$ & 24.56 & $8.67^{\mathrm{a}}$ & $8.93^{\mathrm{a}}$ \\
\hline Control & $8.47^{\mathrm{a}}$ & - & $8.50^{\mathrm{a}}$ & - & $8.47^{\mathrm{a}}$ & - & $7.87^{\mathrm{bc}}$ & $7.87^{\mathrm{c}}$ \\
\hline F-Test & $* *$ & & $* *$ & & $* *$ & & $*$ & $*$ \\
\hline $\operatorname{LSD}(=0.01)$ & 0.66 & & 0.12 & & 0.51 & & 0.75 & 0.55 \\
\hline $\mathrm{CV} \%$ & 5.08 & & 1.46 & & 3.79 & & 5.05 & 3.61 \\
\hline
\end{tabular}

${ }^{\dagger}$ Means of 3 replications. Means in column with same superscript is not significantly different by LSD ${ }_{(\mathrm{P}<0.01) .}$ PDA- Potato Dextrose Agar, MCD- Mean Colony Diameter, MGI- Mycelial Growth Inhibition, Z.- Zanthozylum, A.- Acorus , L.-Lantana

\section{In-vivo test}

Experiment under field condition during 2011-12

All plant extracts had significant (Pd"0.05) effect on crop yield, PDI, disease severity and HSWT over control. The higher crop yield was recorded from the plots sprayed with L. camera $(353.30 \mathrm{~kg} / \mathrm{ha})$ as compared to control plot $(210.50 \mathrm{~kg} / \mathrm{ha})$. The lower PDI was found in the plot treated with $X$. armatum (49.55\%) and A. calamus $(51.66 \%)$ and the higher recorded from control $(72.44 \%)$. The percent disease control of X.armatum $(31.60 \%)$ and A.calamus sprayed plot was found (28.69\%) over control (Table 2 and 3 ).

Table 2. Influence of botanicals on disease severity and yield attributes of lentil at Rampur, Chitwan during 2011/12

\begin{tabular}{|c|c|c|c|c|c|c|c|c|}
\hline $\begin{array}{l}\text { Treatments } \\
\text { Water extract }\left(8 \% \text { conc }^{n}\right)\end{array}$ & EPS & $\begin{array}{l}\text { STB } \\
\text { (1-9scale) }\end{array}$ & FPS & PHT (cm) & $\begin{array}{l}\text { POD/ } \\
\text { plant }\end{array}$ & $\begin{array}{l}\text { SEED/ } \\
\text { pod }\end{array}$ & $\begin{array}{l}\text { YIELD } \\
\text { (kg/ha) }\end{array}$ & $\begin{array}{c}\text { HSWT } \\
\text { (gm) }\end{array}$ \\
\hline$X$. armatum (Nepal pepper) & $2.50^{b \dagger}$ & $4.50^{c}$ & $3.25^{\mathrm{abc}}$ & $28.75^{\mathrm{a}}$ & $39.75^{b}$ & $1.75^{\mathrm{a}}$ & $230.30^{\mathrm{c}}$ & $1.60^{\mathrm{ab}}$ \\
\hline A. indica (Mug-wort) & $2.75^{b}$ & $6.00^{\mathrm{ab}}$ & $3.50^{\mathrm{ab}}$ & $29.00^{\mathrm{a}}$ & $35.00^{c}$ & $2.00^{\mathrm{a}}$ & $281.50^{b}$ & $1.60^{\mathrm{ab}}$ \\
\hline A. indica $(\mathrm{Neem})$ & $2.50^{b}$ & $6.00^{\mathrm{ab}}$ & $3.00^{\mathrm{bc}}$ & $28.50^{\mathrm{a}}$ & $38.00^{\mathrm{bc}}$ & $1.50^{\mathrm{ab}}$ & $260.00^{b}$ & $1.50^{\mathrm{b}}$ \\
\hline A. calamus (Sweet flag) & $3.75^{\mathrm{a}}$ & $5.00^{\mathrm{bc}}$ & $3.75^{\mathrm{a}}$ & $29.25^{\mathrm{a}}$ & $44.50^{\mathrm{a}}$ & $2.00^{\mathrm{a}}$ & $231.00^{\mathrm{c}}$ & $1.70^{\mathrm{a}}$ \\
\hline L camera (Lantana) & $2.50^{\mathrm{b}}$ & $5.00^{\mathrm{bc}}$ & $2.75^{\mathrm{c}}$ & $30.00^{\mathrm{a}}$ & $40.50^{\mathrm{ab}}$ & $1.50^{\mathrm{ab}}$ & $353.30^{\mathrm{a}}$ & $1.67^{\mathrm{a}}$ \\
\hline Control & $2.50^{\mathrm{b}}$ & $7.00^{\mathrm{a}}$ & $3.75^{\mathrm{a}}$ & $26.75^{\mathrm{b}}$ & $29.25^{\mathrm{d}}$ & $1.00^{b}$ & $210.50^{c}$ & $1.52^{b}$ \\
\hline F-Test & $*$ & $*$ & $*$ & & $* *$ & $*$ & $* *$ & $* *$ \\
\hline $\operatorname{LSD}(=0.05)$ & 0.84 & 1.34 & 0.71 & 1.64 & 4.30 & 0.59 & 28.24 & 0.11 \\
\hline $\mathrm{CV} \%$ & 20.28 & 15.91 & 14.14 & 3.79 & 7.54 & 24.05 & 7.18 & 4.61 \\
\hline
\end{tabular}

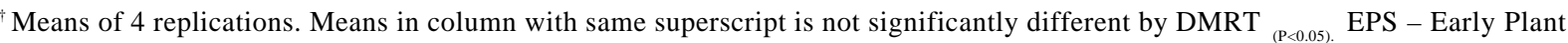
Stand per plot, STB - Stemphylium blight, FPS - Final Plant Stand/plot, PHT- Plant Height, POD- Pod per Plant, SEED- Seed per pod, YIELD- Grain yield, HSWT- Hundred Seed Weight 
Nepal Journal of Science and Technology Vol. 16, No.1 (2015) 11-16

Table 3. Effect of botanicals on PDI, PDC and PYI of lentil during 2011/12 at Rampur, Chitwan

\begin{tabular}{|c|c|c|c|c|}
\hline $\begin{array}{l}\text { Treatments } \\
\text { Water extract }\left(8 \% \text { conc }{ }^{\mathrm{n}}\right)\end{array}$ & $\begin{array}{l}\text { Disease Index } \\
\text { (PDI) }(\%)\end{array}$ & $\begin{array}{l}\text { Disease Control } \\
\text { (PDC) }(\%)\end{array}$ & $\begin{array}{l}\text { Grain Yield } \\
\text { (kg/ha) }\end{array}$ & $\begin{array}{l}\text { Yield } \\
\text { Increase (\%) }\end{array}$ \\
\hline X. armatum (Nepal pepper) & $49.55^{\mathrm{d \dagger}}(44.74)$ & 31.60 & $230.30^{c}$ & 9.40 \\
\hline A. indica (Mug-wort) & $62.88^{\mathrm{b}}(52.48)$ & 13.20 & $281.50^{b}$ & 33.73 \\
\hline A. indica $(\mathrm{Neem})$ & $61.55^{\mathrm{b}}(51.70)$ & 15.03 & $260.00^{b}$ & 23.52 \\
\hline A. calamus (Sweet flag) & $51.66^{\mathrm{c}}(45.96)$ & 28.69 & $231.00^{\mathrm{c}}$ & 9.74 \\
\hline L. camera (Lantana ) & $52.44^{\mathrm{c}}(46.40)$ & 27.61 & $353.30^{\mathrm{a}}$ & 67.84 \\
\hline Control & $72.44^{\mathrm{a}}(58.33)$ & - & $210.50^{\mathrm{c}}$ & - \\
\hline F-Test & ** & & ** & \\
\hline $\operatorname{LSD}(=0.05)$ & 1.18 & & 28.24 & \\
\hline $\mathrm{CV} \%$ & 1.57 & & 7.18 & \\
\hline
\end{tabular}

${ }^{\dagger}$ Means of 4 replications. Means in column with same superscript is not significantly different by DMRT ${ }_{(\mathrm{P}<0.05) .}$ Mean in parenthesis is of arcsine transformed data

\section{Experiment under field condition during 2012/13}

All botanicals had significant effect $(\mathrm{P} \leq 0.05)$ on PDI, grain yield and hundred seed weight (HSWT) over control. The disease control (PDC) was higher in $A$. calamus (46.60) and $X$. armatum (46.26) compared to control plot. The higher yield increase $(\%)$ was obtained from A. calamus treated plot (91.50) over control (Table 4).

Table 4. Effect of botanicals on disease severity and yield performance of lentil at Rampur, Chitwan during 2012/ 13

\begin{tabular}{|c|c|c|c|c|c|c|c|c|}
\hline $\begin{array}{l}\text { Treatments } \\
\text { Water extract }\left(8 \% \text { conc }^{n}\right)\end{array}$ & $\operatorname{EPS}(\%)$ & $\begin{array}{l}\text { DS } \\
(1-9 \\
\text { scale })\end{array}$ & PDI & $\operatorname{FPS}(\%)$ & $\begin{array}{l}\text { YIELD } \\
\text { (kg/ha) }\end{array}$ & $\begin{array}{c}\text { HSWT } \\
\text { (gm) }\end{array}$ & $\begin{array}{l}\text { PDC } \\
(\%)\end{array}$ & YI $(\%)$ \\
\hline X. armatum (Nepal pepper) & $85.00^{\dagger}$ & $4.00^{\mathrm{de}}$ & $35.55^{\mathrm{d}}$ & $79.00^{\mathrm{ab}}$ & $972.78^{\mathrm{a}}$ & $1.77^{\mathrm{a}}$ & 46.26 & 88.67 \\
\hline A. indica (Mug-wort) & 87.50 & $6.00^{\mathrm{bc}}$ & $49.28^{\mathrm{bc}}$ & $82.00^{\mathrm{a}}$ & $680.53^{\mathrm{b}}$ & $1.54^{\mathrm{a}}$ & 25.50 & 32.00 \\
\hline A. indica $(\mathrm{Neem})$ & 83.75 & $6.50^{\mathrm{ab}}$ & $53.78^{\mathrm{b}}$ & $77.50^{\mathrm{b}}$ & $668.00^{\mathrm{b}}$ & $1.54^{\mathrm{a}}$ & 18.70 & 29.60 \\
\hline A. calamus (Sweet flag) & 86.25 & $3.00^{\mathrm{e}}$ & $35.33^{\mathrm{d}}$ & $82.00^{\mathrm{a}}$ & $987.39^{\mathrm{a}}$ & $1.88^{\mathrm{a}}$ & 46.60 & 91.50 \\
\hline L. camera (Lantana) & 86.25 & $5.00^{\mathrm{cd}}$ & $42.53^{\mathrm{c}}$ & $81.00^{\mathrm{ab}}$ & $697.23^{b}$ & $1.64^{\mathrm{a}}$ & 35.71 & 35.22 \\
\hline Control & 78.75 & $7.50^{\mathrm{a}}$ & $66.15^{\mathrm{a}}$ & $71.00^{\mathrm{c}}$ & $515.62^{c}$ & $1.43^{\mathrm{a}}$ & - & - \\
\hline F-Test & NS & $* *$ & $* *$ & $* *$ & $* *$ & $*$ & & \\
\hline $\operatorname{LSD}(=0.05)$ & & 1.054 & 6.78 & 3.83 & 142.69 & 0.05 & & \\
\hline $\mathrm{CV} \%$ & 5.32 & 13.11 & 9.55 & 3.23 & 12.56 & 2.22 & & \\
\hline
\end{tabular}

${ }^{\dagger}$ Means of 4 replications. Means in column with same superscript is not significantly different by DMRT (P<0.05). EPS - Early Plant Stand per plot, DS - Disease severity, PDI- Percent Disease Index (25 plants), FPS - Final Plant Stand/plot, YIELD- Grain yield, HSWT- Hundred Seed Weight, PDC- Percent Disease Control, YI- Yield Increase, NS- Not Significant, ** - Highly significant, $\mathrm{Conc}^{\mathrm{n}}-$ Concentration

\section{Relationship between PDC and yield increase over the control}

In 2012-2013 the higher PDC and corresponding yield was given by $A$. calamus $(8 \% \mathrm{~W} / \mathrm{V})$ followed by $X$. armatum $(8 \% \mathrm{~W} / \mathrm{V})$. A positive linear correlation between PDC and PYI was observed during 2012/13. Equation $Y=1.871 X-7.736$ and $R^{2}=$ 0.857 gave the best fit (Fig. 1).

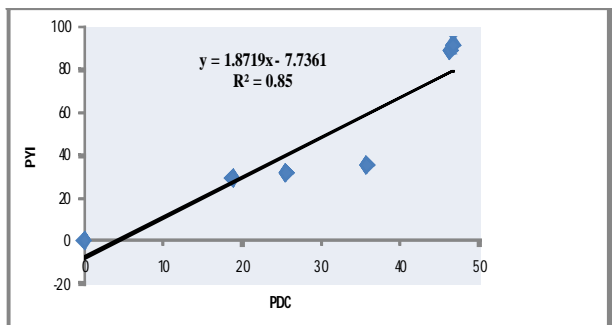

Fig.1. Relationship between PDC and PYI of botanicals used in Stemphylium blight management experiment at Rampur, Chitwan during 2012/13 
Management of plant disease successfully achieved through application of botanicals, chemicals and biological control methods. Stemphylium blight disease is relatively a new emerging disease in Nepal and very few researches have been done to cope up with this disease. Some noticeable research works were undertaken in Bangladesh to manage stemphylium blight which was their major yield reducing factor of lentil. From the present study, it is concluded that $A$. calamus and $X$. armatum were effective botanicals to suppress the growth of $S$. botryosum. Phongpaichit etal. (2005) investigated that an antimicrobial guided one of methanol extracts of $A$. calamus containing b-asarone as a major component showing high antifungal activity againstMicrosporum gypseum, Trichophyton rubrum and Penicillium marneffe $i$ and had moderate activity against $C a n d i d a$ albicans and Cryptococcus neoformans. Findings of current study are in agreement with the report of Deena and Thoppil (2000) who described the essential oil of L. camera containing B-caryophyllene, geranyl acetate, terpinyl acetate, bornyl acetate and limonene remarkably inhibited the growth of many tested bacteria and fungi. Aspergillus niger, Fusarium solani and Candida albicans appeared as the most sensitive ones.

\section{Conclusion}

Control through botanical and biological means are very effective against any plant diseases. The findings of two consecutive years showed that A. calamus and $X$. armatum have the potentials to suppress the radial colony growth of $S$. botryosum and also timely application was effective in vivo for stemphylium blight disease control and yield increment. It was noted that the yield of lentil was enhanced through the application of botanicals. From this study, it is clear that disease index (percent) was less in botanicals sprayed plots compared to that of control plots. Result showed $A$. calamus as the most effective botanical followed by $X$. armatum when tested both at in vitro and in vivo conditions. Thus, it is recommended to spray A. calamus (8\% W/V) thrice at an interval of 15 days from the day of first appearance of disease in the field with respect to disease control and yield increment of lentil.

\section{Acknowledgements}

The authors are grateful to the grain legume coordinator for his support to carry out the experiments and providing physical facilities to prepare this report. Our sincere thanks go to the Plant Pathology Division for making arrangements and valuable suggestions to conduct the experiments.

\section{References}

Bakr, M.A. 1991. Plant protection of lentil in Bangladesh. In: Proceedings of the seminar on lentil in South Asia (11-15 March, 1991). New Delhi, India. pp. 15- 24.

Deena, M.J. and J.E. Thoppil. 2000. Antimicrobial activity of the essential oil of L. camara. Fitoter 71: 453-5.

Erskine, W. and A. Sarker. 1997. Lentil: The Bangladesh breakthrough. ICARDA Caravan No. 6. Aleppo, Syria. $14 \mathrm{pp}$.

ICARDA. 2012. Legume international nurseries and trials. International Center for Agriculture Research in Dry Areas, Aleppo, Syria. pp-5.

Joshi, S. 2006. Review of important grain legume diseases and their management. In: Proceedings of a national workshop on integrated pest management (IPM). Plant Protection Society of Nepal. Kathmandu, Nepal. pp100-116.

Morrall, R.A.A. and D.L. Mckenzie. 1974. A note on the inadvertent introduction to North America of Ascochyta rabiei, a destructive pathogen of chickpea. Plant Disease Reporter 58:342-345.

Phongpaichit, S., N. Pujenjob, V. Rukachaisirikul and M. Ongsakul. 2005. Antimicrobial activities of the crude methanol extract of Acorus calamus Linn. Songklanakarin J. Sci. Technol. 27(Suppl. 2): 517523.

Shivankar, S.K. and P.D. Wangikar. 1993. Effect of different fungicides on the control of gray mildew disease of cotton. Indian Phytopath. 46 (3): 230-235.

Wheeler, B.E.J. 1969. An introduction to plant diseases. John Wiley and Sons. Ltd., London. pp. 301.

Wokocha, R.C and V.C. Okereke. 2005. Fungitoxic activity of extracts of some medicinal plants on Sclerotium rolfsii causal organism of the basal stem rot diseases of tomato. Niger. J. Plant Prot. 22:106-110. 
Nepal Journal of Science and Technology Vol. 16, No.1 (2015) 11-16 